\title{
Breaking through the postwar coverup of Nazi doctors in Germany
}

\author{
Christian Pross Berlin, Germany
}

When a dictatorial regime collapses the former power elite, the perpetrators, helpers and collaborators of the old regime do not vanish but, as history has repeatedly shown, manage to survive quite agreeably. This survival is made the more likely by the fact that many of them are, or make themselves, irreplaceable and indispensable as professionals. Such was the situation in Germany after the liberation from Nazism in 1945. In postwar Germany exposing the perpetrators was particularly difficult, because Germany was not liberated by a strong internal anti-Hitler opposition but by the Allied forces. So there was hardly a powerful group within Germany willing or capable of depriving the perpetrators of their continuing power. Denazification was not implemented by the Germans but by the Allies, and although the Nuremberg Trials were a great achievement, they hardly incited effective follow-up trials on the part of the German judiciary. Furthermore, the change of the international political scene with the rupture of the anti-Hitler coalition and the outbreak of the Cold War between the Soviet Union and the Western Allies, paralysed the denazification process in Germany. Former Gestapo and SS intelligence officers became most welcome experts for American and British intelligence operations in the East. Klaus Barbie is the best known example (1). The Soviet Union and communist regimes in Eastern Europe similarly recruited former Gestapo and SS officers for their own intelligence services (2).

Doctor perpetrators in Germany enjoyed particular protection. Kurt Ploetner, SS doctor at Dachau concentration camp, in 1946 was requested by the French to be extradited to stand trial for having directed Mescalin experiments on French prisoners to 'eliminate their will'. US intelligence reported to the French authorities that they could not get hold of him because he was believed to be living in the Soviet zone (3). His experiments provided important material for the CIA's mind control experiments with cannabis, mescalin and LSD in the fifties and sixties (4). It is doubtful whether the American authorities ever made any effort to arrest Ploetner; he taught medicine at the University of Freiburg in the sixties and was interrogated by a Munich State attorney about his involvement in the fatal malaria experiments at
Dachau. Yet the indictment was dropped in 1972. In $\vec{\nabla}$ fact he was never indicted for his mescalin experiments (5). In 1945, Karl Sperber, a Czechoslovakian doctor and survivor of Auschwitz, had the foresight to warn the world: 'There is a tradition that doctors do not readily let each other down. But God forbid that, as the concentration camps fade into oblivion and the world $\vec{\square}$ meets again to exchange ideas and discoveries at $\stackrel{\mathbb{}}{\circ}$ international conferences, any surgeon or doctor should say of the German doctors of the concentration camps: "After all these men are scientists, men like us, $\stackrel{\mathscr{D}}{-}$ and we must sit next to them and exchange ideas wi $\overrightarrow{0}$ them if medical science is not to suffer or perish". T오 those who forgive and forget too quickly I dedica these lines' (6).

Alexander Mitscherlich and Fred Mielke, the official observers from the West German Chambers of Physicians at the Nuremberg doctors' trial, had the $\stackrel{\circ}{\mathbb{D}}$ courage to break the esprit de corps of their own $\cong$ profession. They published trial documents which $\overline{0}$ charged Germany's top surgeon, Ferdinand Sauerbruch, and Wolfgang Heubner, director of the Pharmacological Institute of Berlin University, of being accessories to medical crimes for participating in a conference on the extremely cruel and partly fatal sulfonamide experiments in Ravensbrück (7). Mitscherlich had to pay a high price for his resoluteness. Sauerbruch and Heubner sued him and $\ni$ forced him to remove this paragraph from the trial 0 report. At the same time the leading Göttingen physiologist and specialist of aviation medicine, $\frac{D}{0}$ Freidrich Rein, accused Mitscherlich of irresponsibly attacking the pillars of scientific research and of $\mathcal{N}$ dishonouring the German medical profession (8)

In 1949 the final version of Mitscherlich's $N$ documentation of the Nuremberg doctors' trial was $\omega$ published (9). Ten thousand copies were printed exclusively for the members of the West German Chambers of Physicians. But the book did not become $\stackrel{\Phi}{+}$ known to the public. There were no reviews, no letters $?$ to the editor. 'It was as if the book had never been written', Mitscherlich recalled. One must assume that $\mathbb{\nabla}$ the 10,000 copies disappeared into the archives of the $\frac{O}{1}$ West German Chambers of Physicians without a single $\varrho$ German doctor ever having read the book. However, the World Medical Association received a copy and 
accepted it as proof that the German medical profession had distanced itself from the medical crimes committed under the Nazis and was thus qualified for renewed membership (10).

In the three decades following the Nuremberg doctors' trial there was a very effective complicity of silence and coverup in the German medical profession. This is partly due to the fact that the percentage of doctors in the Nazi party (45 per cent) and its elite organisations, the SA [Sturm Abteilung: the Stormtroopers of the Nazi party, the Brownshirts] (26 per cent) and SS ( 7 per cent), was the highest of all the professions (11). Hardly any of the antifascist refugee doctors returned to Germany after 1945, so there was virtually no antifascist voice within the profession. In the postwar doctors' chambers and panel practice associations former Nazi doctors' leaders occupied key positions. Two postwar presidents of the West German Chambers of Physicians were former SS members. Dr Hans Joachim Sewering, the last president, was forced to resign but remained president of the Bavarian Chamber of Physicians (12). In the fifties, sixties and seventies it was virtually impossible to break the powerful phalanx of defence and denial.

Of the fourteen doctors who are known to have worked in the killing hospitals for the mentally ill and the handicapped under the euthanasia programme with the code name Aktion T4, only one was sentenced in court after 1945. Four died during World War II, two committed suicide. The remaining eight either lived under false names and practised medicine for many years, protected by their colleagues who knew their identity, or evaded trial by fleeing abroad or by acquiring expert opinions from doctor colleagues who declared them too sick to stand trial (13). It is striking how willingly German doctors were prepared to cover up for their criminal colleagues with false medical diagnoses and on the other hand how fussy and reluctant they were in acknowledging the severe illnesses of Nazi victims, for whom they had to provide expert opinions in compensation trials (14).

A prominent example of the widespread coverup is provided by one of the directors of euthanasia Aktion T4 who was head of the psychiatric clinic of Würzburg University, Werner Heyde. After the war he practised medicine for fourteen years under the pseudonym $\mathrm{Dr}$ Sawade in the state of Schleswig Holstein in Northern Germany. His identity was concealed by the whole local medical establishment, including well respected university professors. Employed by the state health administration he gave expert testimony in disablement benefit claims and even in compensation claims of Nazi victims. When by chance his true identity became publicly known, he was arrested and an extensive trial was prepared by the state attorney of the state of Hessen, Fritz Bauer, one of the few courageous attorneys in postwar Germany, who had been persecuted under the Nazis and who later conducted the Frankfurt Auschwitz trial. During the Heyde interrogations Bauer tried to uncover and indict the entire former T4 establishment. Some of its former members had been living underground, and some had fled to South America where they carried on their operations. They tried to free Heyde from prison. The operation failed and a co-defendant of Heyde, who was an important witness, died under mysterious circumstances. Finally Heyde himself evaded trial by committing suicide. The Heyde story sounds as though it were taken from a classical movie about the mafia (15).

In the historiography of Nazi medicine the tide was turned during a national conference of doctors and health workers called the Gesundheitstag, held in West Berlin in May, 1980. It was a deliberate counterconference held during the annual meeting of the Deutsche Ärztetag, the conference of the West German Chambers of Physicians, whose host, the president of the Berlin chamber, was a former SA member. As an attempt to reanimate disrupted alternative models of health care established in the Weimar period, the organisers of the Gesundheitstag had invited five Jewish refugee doctors from abroad, some of whom were former members of the Socialist Doctors Association (Verein Sozialistischer Ärzte). Medicine under National Socialism: Repressed Past Unbroken Tradition? was the title of the conference, which presented the work of a small group of outsiders for the first time (16). The Gesundheitstag inspired a whole new generation of scholars, who studied the mass sterilisations (17), the killing of the mentally ill during the euthanasia Aktion T4 (18), research on the victims of euthanasia (19), the purge of Jewish doctors (20), and the role of anthropologists and geneticists in the racial classification and selection of Jews, gypsies and others who were classed as 'subhumans' (21).

In recent years German doctors have faced growing concern from abroad on the issue of Nazi medicine. At the 1986 meeting of the American College of Neuropsychopharmacology a German scientist was questioned about the origin of the histological brainspecimen dating from the early forties, which he had used for his research and had presented at the meeting. It turned out that the specimens he had used originated from victims of euthanasia (22). Doctors in Israel and the United States expressed concern about the use of anatomical specimens from Nazi victims by German medical schools for teaching purposes. The pressure from abroad finally forced several universities and the prestigious Max Planck Institute for Brain Research to remove all specimens of Nazi victims from their collections and bury them (23), among them the Hallervorden collection in the Max Planck Institute for Brain Research in Frankfurt. Julius Hallervorden, the grand old man of German neuropathology had collected hundreds of brain specimens from euthanasia victims in the early forties. The speech the director of the Institute for Brain Research of the University of Tübingen, Professor Jürgen Peiffer, gave at the burial in Tübingen shows how the debate of the past ten years has stimulated leading representatives of academic 
medicine to confront the past of their own profession. Peiffer, who served as a soldier in World War II, confesses in his speech that he admired and respected Hallervorden, as a friendly colleague and dedicated teacher. He then tries to find a lighter way of judging Hallervorden's guilt. It goes along these lines: although Hallervorden may have had doubts about the legality of his actions he was so dazzled by his scientific curiosity and ambition that he was obviously not aware of serving as a cog-wheel in an inhumane machinery of extermination. The zeal of scientists like Hallervorden, Peiffer suggests, thus morally legitimised the crimes of the actual 'death doctors' (24). Peiffer, stimulated by Götz Aly's research on Hallervorden (25), has since initiated a controversial debate on Hallervorden in the German Neuropathological Society and is currently working on a detailed history of the criminal involvement of a number of German neuropathologists in the Third Reich.

The impact of this public debate and of the numerous publications of the past ten years has been powerful enough to force the West German Chambers of Physicians to change its attitude at last. In May 1989 the Berlin Chamber of Physicians, which was by then controlled by the organisers of the 1980 Gesundheitstag, used the opportunity of being the host of the 1989 annual meeting of the Deutsche Arztetag, to persuade its president, Karsten Vilmar, to put medicine under the Nazis on the agenda. Vilmar agreed that the Berlin chamber should mount an exhibit, which was officially opened at the annual meeting in May 1989 in Berlin (26). There was considerable resistance from several state physicians' chambers, including the Bavarian chamber, which refused to share the costs for the exhibit. At the opening of the exhibit, Richard Toellner, medical historian at the university of Münster, stated in a widely noted speech based on recent research, that 'the whole spectrum of normal representatives of the medical profession was involved and they all knew what they were doing ... . A medical profession, which accepts mass murder of sick people as normal, and to a large degree explicitly approves of it as a necessary, justified act for the sake of the community, has failed and betrayed its mission. Such a medical profession as a whole has become morally guilty, no matter how many members of the profession directly or indirectly participated in the killing of sick people in a legal sense'. This clear statement was printed in the Deutsche Ärzteblatt and must be seen as a new interpretation of history, from which the German medical profession can no longer retreat (27).

Yet there is no reason to be satisfied. The revelations about the medical abuses during the Third Reich are more than forty years late; most of the perpetrators are retired or dead. Justice for the victims and punishment of the perpetrators is no longer possible. Similarly contemporary victims of human rights abuses in Latin America, Asia, Africa and Eastern Europe experience that the perpetrators are virtually never punished unless the international public becomes aware and pushes for justice. The World Medical Association was fooled in 1949 and kept silent on the coverup of the Nazi medical abuses in postwar Germany. The world's medical community should not be fooled again: it should break the complicity of silence towards contemporary abuses.

Christian Pross, MD, Rehabilitation Centre for Torture Victims, Ärztekammer Berlin, clo Klaus-Groth-Str 3, 1000 Berlin 19, Germany.

\section{References}

(1) Marcel Ophuls's documentary film, Hotel Terminus: the life and times of Klaus Barbie, gives a detailed account of the recruitment of the former Gestapo chief of Lyon, Klaus Barbie, by US Intelligence after 1945.

(2) Simpson C. Blowback - America's recruitment of Nazis and its effects on the Cold War. New York: Weidenfeld and Nicholson, 1988: 78-79.

(3) Bernadac C. Les medecins maudits. Paris: Editions France-Empire, 1967: 58-62. Based on records pertaining to Dr Kurt Ploetner, United States Army Intelligence and Security Command, Fort Meade, Maryland.

(4) Marks J. The CIA and mind control: the search for the Manchurian candidate. New York: McGraw-Hill Book Company, 1980: 4ff.

(5) Zentrale Stelle der Landesjustizverwaltungen? Ludwigsburg, Akten der Verfahren gegen Kurt Ploetner.

(6) Leo Alexander Papers; Box 55; folder 'International Commission'; Boston University, Mugar Library.

(7) Mitscherlich A, Mielke F. Das diklat der menschenverachtung. Heidelberg: Verlag Lambert Schneider, 1947: 83-84.

(8) Rein, Sauerbruch and Heubner's campaign against Mitscherlich is documented in the Göttinger Universitätszeitung 1947; 14: 3-5: 1947; 17/18: 6-8: 1948; 3: 4-7: and 1948; 10: 6-8.

(9) Mitscherlich A, Mielke F. Wissenschaft ohne menschlichkeit. Heidelberg: Verlag Lambert Schneider, 1949.

(10) Mitscherlich A, Mielke F. Medizin ohne menschlichkeit. Frankfurt: Fischer Verlag, 1978: 15.

(11) Kater M. Medizin und Mediziner im Dritten Reich. , Historische zeitschrift ; 244: 311-315.

(12) Kater $\mathbf{M}$. The burden of the past: problems of modern historiography of physicians and medicine in Nazi Germany. German studies review 1987; 10: 41-42.

(13) Klee E. Was sie taten, was sie wurden. Frankfurt: Fischer Taschenbuch-Verlag, 1986: 94ff.

(14) For a detailed account of the attitude of German doctors in compensation trials of Nazi victims see: Pross C. Wiedergutmachung - der kleinkrieg gegen die Opfer. Frankfurt: Athenäum Verlag, 1988.

(15) See reference (13): 19ff.

(16) The proceedings of the Gesundheitstag 1980 were published in: Baader G, Schultz U, eds. Medizin und nationalsozialismus, tabuisierte vergangenheit ungebrochene tradition? Berlin: Verlagsgesellschaft Gesundheit, 1980.

(17) Bock G. Zwangssterilisation im nationalsozialismus. 
Opladen: Westdeutscher Verlag, 1986.

(18) Klee E. Euthanasie im NS-staat, die vernichtung lebensunwerten Lebens. Frankfurt: Fischer Verlag, 1983.

(19) Aly G. Der saubere und der schmutzige fortschritt. In: Reform und gewissen, beiträge zur nationalsozialistischen gesundheits - und sozialpolitik, (vol 2). Berlin: Rotbuch Verlag, 1985.

(20) Pross C, Winau R, eds. Nicht mibhandeln, das krankenhaus moabit 1920-1933, ein zentrum jüdischer ärzte in Berlin, 1933-1945, verfolgung widerstand zerstörung. Berlin: Edition Hentrich, 1984.

(21) Müller-Hill B. Tödliche wissenschaft, die aussonderung von Fuden, zigeunern und geisteskranken 1933-1945. Reinbeck: Rowohlt Taschenbuchverlag, 1984.

(22) Rogers B, Becker B M, Gershon E S et al. The brains of the Vogt collection, [letter]. Archives of general psychiatry 1988; 45: 774-776.

(23) Seidelman W E. In memoriam: medicine's confrontation with evil. Hastings Center report, 1989; Nov/Dec: 5-6. Meanwhile the University of Heidelberg has buried all anatomical specimens of Nazi victims. The
University of Tübingen buried their specimen on July 8 , 1990 in an official memorial ceremony. The Max Planck Gesellschaft buried the brain specimen from the Hallervorden collection in an unspectacular closed ceremony in Frankfurt in December 1990.

(24) Peiffer J. Gedenkrede. Erinnern und bedenken: Tübinger universitätsreden 1991; 41: 11-21.

(25) Götz Aly discovered the Hallervorden collection in the Max Planck Institute for Brain Research in Frankfurt in the early eighties and published his findings in 1985: See reference (19).

(26) An exhibit catalogue was published containing an anthology of scientific contributions: Der wert des menschen, medizin in Deutschland 1918-1945. Edited by the Ärztekammer Berlin in Zusammenarbeit mit der Bundesärztekammer; Redaktion Pross C, Aly G. Berlin: Edition Hentrich, 1989.

(27) Toellner R. Ärzte im dritten reich, wortlaut des vortrages, gehalten auf der 1. Plenarsitzung des 92 . Deutschen Ärztetages in Berlin. Deutsches Ärzteblatt 86, Heft 33. 1989 Aug 17: 1427-1433. 